\title{
The Effect of Alkaline Activator Types on Strength and Microstructural Properties of Geopolymer from Co-Combustion Residuals of Bamboo and Kaolin
}

\author{
Aprilina Purbasari ${ }^{1,2, *}$, Tjokorde Walmiki Samadhi ${ }^{1}$, and Yazid Bindar ${ }^{1}$ \\ ${ }^{1}$ Chemical Engineering Program, Bandung Institute of Technology, \\ Jl. Ganesha No. 10, Bandung 40132, Indonesia \\ ${ }^{2}$ Chemical Engineering Department, Diponegoro University, \\ Jl. Prof. Soedarto, Kampus Tembalang, Semarang 50275, Indonesia
}

Received July 14, 2017; Accepted February 8, 2018

\begin{abstract}
Geopolymer as a Portland cement substitute had been synthesized from alkaline activation of co-combustion residuals of bamboo and kaolin. Types of used alkaline activators were $\mathrm{NaOH}$ solution, $\mathrm{KOH}$ solution, a mixture of $\mathrm{NaOH}$ solution-water glass, and a mixture of $\mathrm{KOH}$ solution-water glass. Geopolymer with $\mathrm{NaOH}$ solution as activator had a compressive strength which was higher compared to geopolymer with $\mathrm{KOH}$ solution as an activator. However, geopolymer with $\mathrm{NaOH}$ solution-water glass as activator had a compressive strength which was lower compared to geopolymer with $\mathrm{KOH}$ solution-water glass as activator either at room temperature curing or at a curing temperature of $60{ }^{\circ} \mathrm{C}$. The use of water glass with $\mathrm{NaOH}$ or $\mathrm{KOH}$ solution as activator could increase the compressive strength of geopolymer and yielded geopolymer having denser and more homogeneous microstructure seen from SEM images. XRD patterns revealed the presence of sodium aluminosilicate hydrate in geopolymer with $\mathrm{NaOH}$ solution and $\mathrm{NaOH}$ solution-water glass as activators, and potassium aluminosilicate hydrate in geopolymer with $\mathrm{KOH}$ solution and $\mathrm{KOH}$ solution-water glass as activators. Furthermore, FTIR spectra indicated asymmetrical vibration of Si(Al)-O at around $1008 \mathrm{~cm}^{-1}$ related to geopolymer product.
\end{abstract}

Keywords: alkaline activator; bamboo; cement; geopolymer; kaolin

\section{ABSTRAK}

Geopolimer sebagai pengganti semen Portland telah dibuat dari aktivasi alkali residu pembakaran bersama bambu dan kaolin. Jenis aktivator alkali yang digunakan adalah larutan $\mathrm{NaOH}$, larutan $\mathrm{KOH}$, campuran larutan $\mathrm{NaOH}$-water glass, dan campuran larutan $\mathrm{KOH}$-water glass. Geopolimer dengan larutan $\mathrm{NaOH}$ sebagai aktivator mempunyai kuat tekan lebih tinggi dibandingkan geopolimer dengan larutan $\mathrm{KOH}$ sebagai aktivator, tetapi geopolimer dengan larutan $\mathrm{NaOH}$-water glass sebagai aktivator mempunyai kuat tekan lebih rendah dibandingkan geopolimer dengan larutan $\mathrm{KOH}$-water glass sebagai aktivator baik pada pematangan di suhu kamar maupun di suhu $60^{\circ} \mathrm{C}$. Penggunaan water glass dengan larutan $\mathrm{NaOH}$ atau $\mathrm{KOH}$ sebagai aktivator dapat meningkatkan kuat tekan geopolimer dan menghasilkan geopolimer dengan mikrostruktur lebih padat dan lebih homogen dari citra SEM. Pola XRD mengungkapkan adanya natrium aluminosilikat hidrat dalam geopolimer dengan larutan $\mathrm{NaOH}$ solution dan larutan $\mathrm{NaOH}$-water glass sebagai aktivator, dan kalium aluminosilikat hidrat dalam geopolimer dengan larutan $\mathrm{KOH}$ dan larutan $\mathrm{KOH}$-water glass sebagai aktivator. Selanjutnya, spektra FTIR menunjukkan vibrasi asimetris dari Si(Al)-O di sekitar $1008 \mathrm{~cm}^{-1}$ yang berhubungan dengan produk geopolimer.

Kata Kunci: aktivator alkali; bambu; semen; geopolimer; kaolin

\section{INTRODUCTION}

Geopolymer has been developed as a Portland cement substitute. Geopolymer having empirical formula of $\mathrm{Mn}_{\mathrm{n}}\left(-\left(\mathrm{SiO}_{2}\right)_{\mathrm{z}}-\mathrm{AlO}_{2}\right)_{n} \cdot \mathrm{wH}_{2} \mathrm{O}\left(\mathrm{M}=\mathrm{Na}^{+} / \mathrm{K}^{+}\right.$cation; $\mathrm{z}=1,2,3$; $\mathrm{n}=$ degree of polycondensation) is derived from polymerization of materials containing alumino-silicate oxides and alkaline activators at temperature below $100{ }^{\circ} \mathrm{C}$ [1]. Compared to Portland cement production from limestone and clay that takes place at a temperature about $1400{ }^{\circ} \mathrm{C}$ and produces $\mathrm{CO}_{2}$ emissions of 0.9 ton/ton product, geopolymer production needs lower energy consumption and produces lower $\mathrm{CO}_{2}$ emissions (0.09 ton/ton product) [2-3]. Research on geopolymer application as a Portland cement substitute has shown that geopolymer has high mechanical strength, fire resistance, and acid resistance characteristics [4].

* Corresponding author

Email address : aprilina.purbasari@che.undip.ac.id 
Materials containing alumino-silicate oxides for geopolymer production are natural minerals (e.g., kaolin, metakaolin), solid waste from a combustion process (fly ash, biomass ash), and solid waste from steel industry (slag) [5]. Biomass ash has been utilized as geopolymer raw material, i.e., rice husk ash [6], wood ash [7] and palm oil fuel ash [8]. Bamboo ash contains high silica that can be utilized as geopolymer raw material. Cocombustion of bamboo and kaolin as additives produces residuals containing high silica and high alumina [9]. The addition of kaolin in bamboo combustion as energy source aims to prevent the occurrence of sintering and slag formation caused by alkali in bamboo ash.

The mechanism of the geopolymerization reaction is as follows [2]:

$$
\begin{aligned}
& \left(\mathrm{Si}_{2} \mathrm{O}_{5}, \mathrm{Al}_{2} \mathrm{O}_{2}\right) \mathrm{n}+\mathrm{nH}_{2} \mathrm{O} \stackrel{\mathrm{KOH}, \mathrm{NaOH}}{\longrightarrow} \mathrm{n}(\mathrm{OH})_{3}-\mathrm{Si}-\mathrm{O}-\mathrm{Al}-(\mathrm{OH})_{3} \\
& \text { Alumino-silicate material Orthosialate }
\end{aligned}
$$

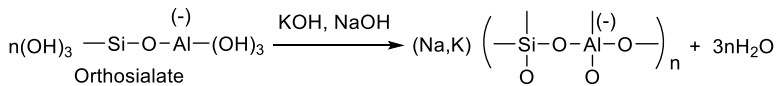

$$
\begin{aligned}
& (\mathrm{Na}, \mathrm{K}) \text {-poly(sialate })
\end{aligned}
$$

or,

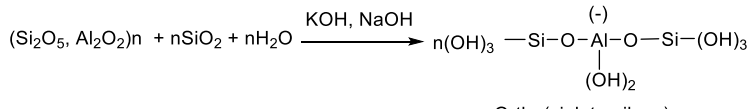

$$
\begin{aligned}
& \text { Ortho(sialate-siloxo) } \\
& \text { Ortho(sialate-siloxo) }
\end{aligned}
$$

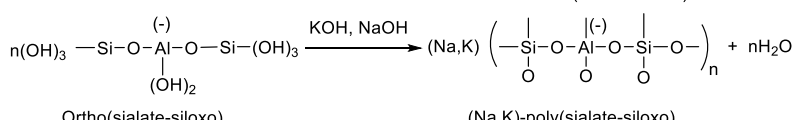

Alumino-silicate material in the presence of an alkaline activator (alkali hydroxide solution or a mixture solution of alkali hydroxide and alkali silicate) will be dissolved, polymerized, and finally hardening to form geopolymer. One of the influencing factors in the geopolymerization process is alkaline activator type [4]. Therefore, this paper presents the effect of alkaline activator types on compressive strength and microstructural properties of geopolymer cement from co-combustion residuals of bamboo and kaolin. Microstructural properties of geopolymer comprised microstructure by scanning electron microscopy, phase analysis by X-ray diffraction and functional group analysis by Fourier transform infrared spectroscopy.

\section{EXPERIMENTAL SECTION}

\section{Materials}

Materials used were apus bamboo (Gigantochloa apus), kaolin powder, river sand, commercial $\mathrm{NaOH}$ flakes (purity of $98 \%$ ), commercial $\mathrm{KOH}$ flakes (purity of $90 \%$ ), and commercial water glass or sodium silicate $\left(\mathrm{SiO}_{2}=30 \%, \mathrm{Na}_{2} \mathrm{O}=9 \%, \mathrm{H}_{2} \mathrm{O}=61 \%\right)$. Apus bamboo was obtained from Central Java, kaolin powder was obtained from Bangka Belitung island region, and river sand was obtained from West Java. Apus bamboo ash contains $\mathrm{SiO}_{2}(58.60 \%), \mathrm{Al}_{2} \mathrm{O}_{3}(0.73 \%), \mathrm{K}_{2} \mathrm{O}(26.43 \%)$, and $\mathrm{Na}_{2} \mathrm{O}(0.51 \%)$; while kaolin contains $\mathrm{SiO}_{2}$ (53.90\%), $\mathrm{Al}_{2} \mathrm{O}_{3}(42.43 \%), \mathrm{K}_{2} \mathrm{O}(1.12 \%)$ and $\mathrm{Na}_{2} \mathrm{O}$ $(0.19 \%)[9]$.

\section{Instrumentation}

\section{Compressive strength test}

The compressive strength tests were conducted by Controls Unitester C21 testing machine on geopolymer mortars. The compressive strength in $\mathrm{MPa}$ unit was calculated by dividing the total maximum load in $\mathrm{N}$ unit by area of the loaded surface in $\mathrm{mm}^{2}$ unit [10].

\section{Microstructure analysis}

SEM images of gold coated specimens were acquired from backscattered electron images using FEI Quanta FEG 450 scanning electron microscope with $500 \times$ magnification.

\section{$X$-ray diffraction analysis}

$X$-ray diffractograms were collected using Panalytical Empyrean X-ray diffractometer employing $\mathrm{Cu} \mathrm{K}_{\alpha}$ radiation. The range of scanning angle $2 \theta$ was from $5^{\circ}$ to $70^{\circ}$.

\section{Fourier transform infrared analysis}

FTIR spectra were recorded by the $\mathrm{KBr}$ pellet technique using Shimadzu IR Prestige-21 FTIR spectrophotometer in the region of $400-4000 \mathrm{~cm}^{-1}$.

\section{Procedure}

\section{Preparation of geopolymer raw materials}

Alumino-silicate materials for geopolymer synthesis were co-combustion residuals of bamboo and kaolin. A mixture of bamboo and kaolin with a weight ratio of 95:5 was combusted first in fixed bed furnace and then combusted in an electric furnace at $550{ }^{\circ} \mathrm{C}$ for $3 \mathrm{~h}$. Co-combustion residuals of bamboo and kaolin contain $\mathrm{SiO}_{2}(52.10 \%), \mathrm{Al}_{2} \mathrm{O}_{3}(33.86 \%), \mathrm{K}_{2} \mathrm{O}$ $(6.92 \%)$ and $\mathrm{Na}_{2} \mathrm{O}(0.11 \%)$ from $\mathrm{X}$-ray fluorescence analysis. Alumino-silicate materials were sieved with 100 mesh standard sieve, while river sand was sieved with 16 mesh standard sieve before used in geopolymer synthesis. Alkaline activators used were $10 \mathrm{~N} \mathrm{NaOH}$ solution, $10 \mathrm{~N} \mathrm{KOH}$ solution, a mixture of $10 \mathrm{~N} \mathrm{NaOH}$ solution and water glass with a weight ratio of $1: 1$, and a mixture of $10 \mathrm{~N} \mathrm{KOH}$ solution and water glass with a weight ratio of $1: 1$.

\section{Synthesis of geopolymer mortars and pastes}

Geopolymer mortars were synthesized from alumino-silicate materials, alkaline activators and sand; 
and used for the compressive strength test. Meanwhile, geopolymer pastes were synthesized from aluminosilicate materials and alkaline activators; and used for SEM, XRD and FTIR analysis. The weight ratio of alkaline activator to the alumino-silicate material was 1.3:1 and weight ratio of sand to the alumino-silicate material was 2.75:1 [10]. Liquid materials were mixed with solid materials and stirred for $6 \mathrm{~min}$. The mixture was poured into $5 \mathrm{~cm} \times 5 \mathrm{~cm} \times 5 \mathrm{~cm}$ cubic molds and cured in molds for $24 \mathrm{~h}$. After all, specimens were removed from the molds, some specimens cured at room temperature for 56 days and some specimens were cured in an oven at $60^{\circ} \mathrm{C}$ for $24 \mathrm{~h}$ and then at room temperature for 56 days.

\section{RESULT AND DISCUSSION}

\section{Compressive Strength}

Compressive strengths of geopolymer mortars with various types of alkaline activators at room temperature and temperature of $60{ }^{\circ} \mathrm{C}$ curing are shown in Fig. 1. Increasing curing temperature from room temperature to $60{ }^{\circ} \mathrm{C}$ can improve the compressive strength of geopolymer mortars. Heat from curing at a temperature of $60{ }^{\circ} \mathrm{C}$ will accelerate dissolution of aluminates and silicates hence geopolymer with higher compressive strength can be obtained for the same curing time [4]. Geopolymer with a mixture of $\mathrm{KOH}$ solution and water glass (WG) as an activator and curing temperature of 60 ${ }^{\circ} \mathrm{C}$ has the highest compressive strength, i.e., 34.3 MPa, meanwhile geopolymer with $\mathrm{KOH}$ solution as activator and room temperature curing has the lowest compressive strength, i.e., 2.3 MPa.

Geopolymers with $\mathrm{NaOH}$ solution or $\mathrm{KOH}$ solution as activators at both room temperature curing and curing temperature of $60{ }^{\circ} \mathrm{C}$ have lower compressive strength than geopolymers with a mixture of $\mathrm{NaOH}$ or $\mathrm{KOH}$ solution-water glass as activators. The use of water glass in the geopolymer synthesis will add dissolved silicates in geopolymer so that molar ratio of $\mathrm{SiO}_{2} / \mathrm{Al}_{2} \mathrm{O}_{3}$ will increase, i.e., from 2.6 to 3.6. In general, the increase of $\mathrm{SiO}_{2} / \mathrm{Al}_{2} \mathrm{O}_{3}$ molar ratio can increase the compressive strength of geopolymer, but $\mathrm{SiO}_{2} / \mathrm{Al}_{2} \mathrm{O}_{3}$ molar ratio $>24$ can produce geopolymer having elastic behavior [11]. The added dissolved silicates can accelerate the geopolymerization process by inducing polymerization of dissolved aluminates and silicates [12]. This causes the obtained geopolymer to have higher compressive strength.

Geopolymer with $\mathrm{NaOH}$ solution as activator has slightly higher compressive strength than geopolymer with $\mathrm{KOH}$ solution as an activator. This can happen

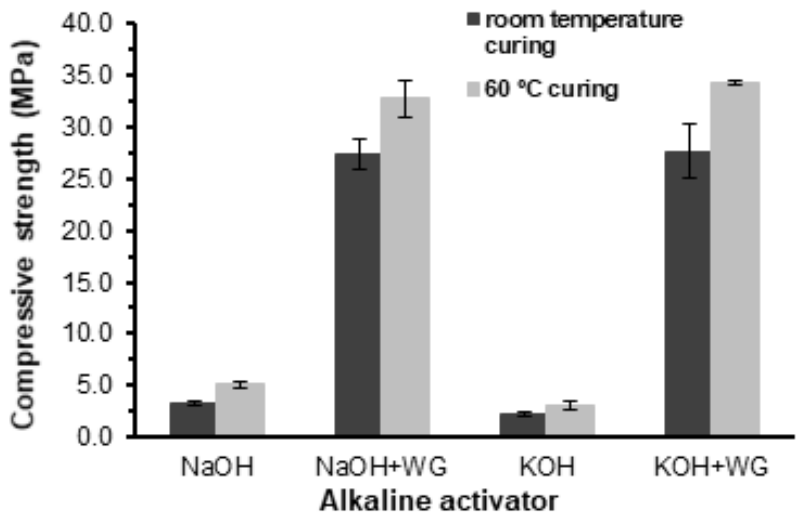

Fig 1. Compressive strengths of geopolymer mortars

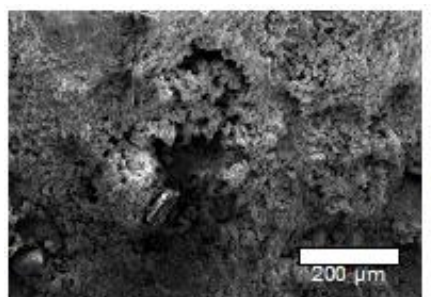

(a)

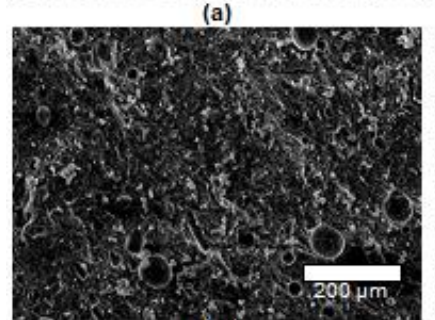

(c)

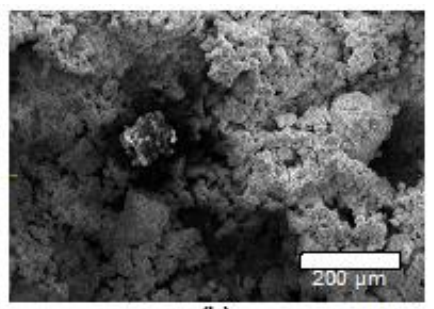

(b)

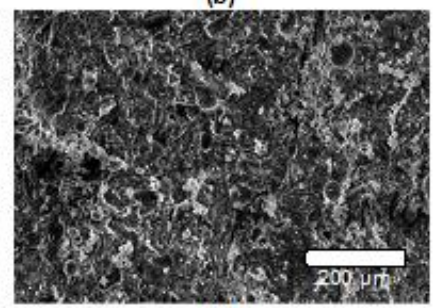

(d)
Fig 2. SEM images of geopolymer paste with $\mathrm{NaOH}$ solution (a), $\mathrm{KOH}$ solution (b), a mixture of $\mathrm{NaOH}$ solution-water glass (c) and mixture of $\mathrm{KOH}$ solutionwater glass (d) as activators

because $\mathrm{Na}^{+}$ion has a smaller size than $\mathrm{K}^{+}$ions so that the dissolution of aluminates and silicates from the alumino-silicate material is more to form geopolymer [13]. The similar results were obtained by Panagiotopoulou et al. [13] and Sindhunata et al. [14]. Different results are shown by geopolymers with a mixture of alkali hydroxide solution and water glass as activators. Geopolymer with a mixture of $\mathrm{KOH}$ solutionwater glass as activator have slightly higher compressive strength than geopolymer with a mixture of $\mathrm{NaOH}$ solution-water glass as an activator. The larger size of $\mathrm{K}^{+}$ion than $\mathrm{Na}^{+}$ion will lead to denser polycondensation in a water glass or alkali silicate solution, and the resulting geopolymer will have higher compressive strength [15]. Studies conducted by van Jaarsveld and van Deventer [15], Cioffi et al. [16], and Sabitha et al. [17] also showed the same results. 


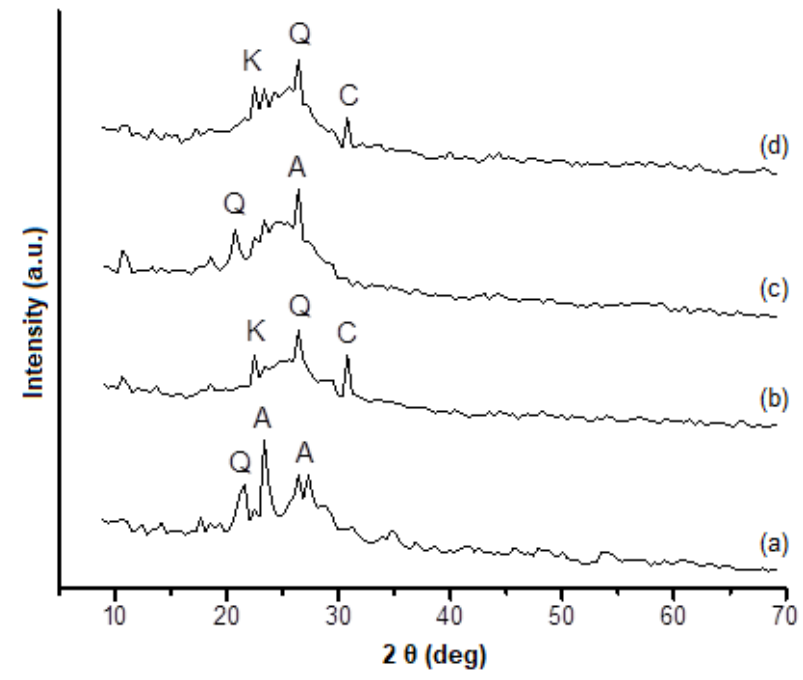

Fig 3. X-ray diffractograms of geopolymer pastes with $\mathrm{NaOH}$ solution (a), $\mathrm{KOH}$ solution (b), mixture of $\mathrm{NaOH}$ solution-water glass (c) and mixture of $\mathrm{KOH}$ solutionwater glass (d) as activators $(\mathrm{A}=$ analcime $\left(\mathrm{Na}\left(\mathrm{AlSi}_{2} \mathrm{O}_{6}\right) \cdot \mathrm{H}_{2} \mathrm{O}\right) ; \mathrm{C}=$ chabazite $\left(\mathrm{K}\left(\mathrm{AlSi}_{2} \mathrm{O}_{6}\right) \cdot 3 \mathrm{H}_{2} \mathrm{O}\right)$; $\mathrm{K}=$ kalsilite $\left(\mathrm{KAISiO}_{4}\right) ; \mathrm{Q}=$ quartz $\left.\left(\mathrm{SiO}_{2}\right)\right)$

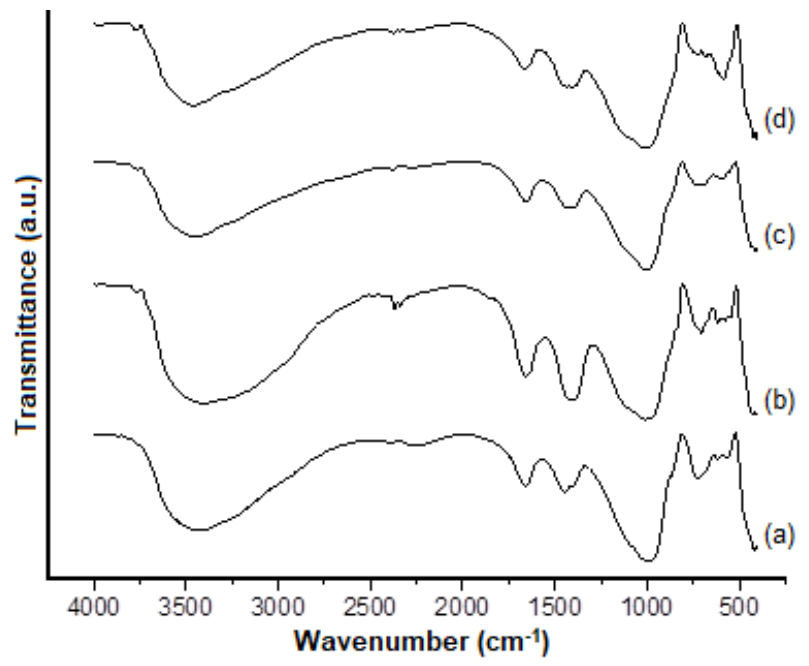

Fig 4. FTIR spectra of geopolymer paste with $\mathrm{NaOH}$ solution (a), $\mathrm{KOH}$ solution (b), a mixture of $\mathrm{NaOH}$ solution-water glass (c) and a mixture of $\mathrm{KOH}$ solutionwater glass (d) as activators

\section{Microstructure of Geopolymers}

The microstructure of geopolymers with various types of alkaline activators are shown in Fig. 2. The uses of $\mathrm{NaOH}$ solution and $\mathrm{KOH}$ solution as alkaline activators produce more porous geopolymers (Fig. 2(a) and 2(b)). Meanwhile, geopolymers with a mixture of $\mathrm{NaOH}$ solution-water glass as well as a mixture of $\mathrm{KOH}$ solution-water glass as activators (Fig. 2(c) and 2(d)) have denser and more homogeneous structures. This is due to the continuous phase formation in geopolymers with alkali hydroxide activators tends to the surface of the particles, whereas in geopolymers containing dissolved silicate from water glass activators tend to the bulk areas [5]. These results are similar to those obtained by van Deventer et al. [18], Zhang et al. [19] and Zhang et al. [20].

\section{X-Ray Diffraction Patterns}

X-ray diffractograms of geopolymers with $\mathrm{NaOH}$ solution and mixture of $\mathrm{NaOH}$ solution-water glass as activators in Fig. 3(a) and 3(c) shows the presence of analcime $\left(\mathrm{Na}\left(\mathrm{AlSi}_{2} \mathrm{O}_{6}\right) \cdot \mathrm{H}_{2} \mathrm{O}\right)$ and quartz $\left(\mathrm{SiO}_{2}\right)$. Analcime is a mineral that has a silico-aluminate framework and commonly encountered in geopolymers [2], whereas quartz mineral is derived from geopolymer raw materials.

Geopolymers with $\mathrm{KOH}$ solution and a mixture of $\mathrm{KOH}$ solution-water glass as activators contain the same minerals, i.e., chabazite $\left(\mathrm{K}_{(}\left(\mathrm{AlSi}_{2} \mathrm{O}_{6}\right) \cdot 3 \mathrm{H}_{2} \mathrm{O}\right)$, kalsilite $\left(\mathrm{KAISiO}_{4}\right)$ and quartz $\left(\mathrm{SiO}_{2}\right)$ as shown in Fig. $3(\mathrm{~b})$ and $3(\mathrm{~d})$. Chabazite and kalsilite are minerals that can be formed in geopolymers with potassium hydroxide as an activator [2]. Kalsilite is also present in geopolymer raw materials from the reaction between alkali (in bamboo) and kaolinite (in kaolin) in the cocombustion process [9].

\section{Fourier Transform Infrared Spectra}

FTIR spectra of geopolymers with various types of alkaline activators as shown in Fig. 4 have relatively similar profiles. The presence of peaks at $950-1250 \mathrm{~cm}^{-1}$ and $420-500 \mathrm{~cm}^{-1}$ derived from Si-O-Si and Si-O-Al groups indicates the formation of geopolymers [2]. The peak shift closer to $1008 \mathrm{~cm}^{-1}$ (theoretically derived from the $\mathrm{Si}(\mathrm{Al})-\mathrm{O}$ group (asymmetrical vibration)) indicates more geopolymers are formed [21]. Geopolymer with mixture $\mathrm{KOH}$ solution-water glass as activator has peak close to $1008 \mathrm{~cm}^{-1}$ so that more geopolymers are formed. This corresponds to the highest compressive strength of geopolymer with a mixture of $\mathrm{KOH}$ solution-water glass as activator compared to geopolymers with other alkaline activators.

Adsorbed atmospheric water is also found in about 1600 and $3400 \mathrm{~cm}^{-1}$ [22]. The carbonate group which is the result of the reaction between alkali hydroxide and atmospheric $\mathrm{CO}_{2}$ was found at 1400 $1500 \mathrm{~cm}^{-1}$ [23]. 


\section{CONCLUSION}

Geopolymers as a Portland cement substitute from co-combustion residuals of bamboo and kaolin with various types of alkaline activators have been synthesized and characterized. Geopolymer with a mixture of $\mathrm{KOH}$ solution and water glass as an activator and curing temperature of $60{ }^{\circ} \mathrm{C}$ has the highest compressive strength, while geopolymer with $\mathrm{KOH}$ solution as activator and room temperature curing has the lowest compressive strength. The use of $\mathrm{NaOH}$ or $\mathrm{KOH}$ solution as alkaline activator produces more porous geopolymer, whereas geopolymer with a mixture of $\mathrm{NaOH}$ or $\mathrm{KOH}$ solution-water glass as activator has denser and more homogeneous structure seen from SEM images. XRD patterns revealed the presence of sodium aluminosilicate hydrate (analcime) in geopolymer with $\mathrm{NaOH}$ solution and a mixture of $\mathrm{NaOH}$ solutionwater glass as activators, and potassium aluminosilicate hydrate (chabazite) in geopolymer with $\mathrm{KOH}$ solution and mixture of $\mathrm{KOH}$ solution-water glass as activators. FTIR spectra of geopolymers with various types of alkaline activators have relatively similar profiles revealing asymmetrical vibration of $\mathrm{Si}(\mathrm{Al})-\mathrm{O}$ at around $1008 \mathrm{~cm}^{-1}$ related to geopolymer product.

\section{ACKNOWLEDGMENT}

The authors are grateful to Laboratory of Mineral and Inorganic Material Technology, Bandung Institute of Technology for providing access to equipment used in this study.

\section{REFERENCES}

[1] Davidovits, J., 1991, Geopolymers: Inorganic polymeric new materials, J. Therm. Anal. Calorim., 37 (8), 1633-1656.

[2] Davidovits, J., 2008, Geopolymer: Chemistry and applications, $2^{\text {nd }}$ ed., Institut Géopolymère, SaintQuentin.

[3] Imbabi, M.S., Carrigan, C., and McKenna, S., 2012, Trends and developments in green cement and concrete technology, Int. J. Sustainable Built Environ., 1 (2), 194-216.

[4] Khale, D., and Chaudhary, R., 2007, Mechanism of geopolymerization and factors influencing its development: A review, J. Mater. Sci., 42 (3), 729746.

[5] van Deventer, J.S.J., Provis, J.L., and Duxson, P., 2012, Technical and commercial progress in the adoption of geopolymer cement, Miner. Eng., 29, 89-104.

[6] Kim, Y.Y., Lee, B.J., Saraswathy, V., and Kwon, S.J., 2014, Strength and durability performance of alkali-activated rice husk ash geopolymer mortar, Sci. World J., 2014, 209584, 1-10.

[7] Rajamma, R., Labrincha, J.A., and Ferreira, V.M., 2012, Alkali activation of biomass fly ashmetakaolin blends, Fuel, 98, 265-271.

[8] Salih, M.A., Ali, A.A.A., and Farzadnia, N., 2014, Characterization of mechanical and microstructural properties of palm oil fuel ash geopolymer cement paste, Constr. Build. Mater., 65, 592-603.

[9] Purbasari, A., Samadhi, T.W., and Bindar, Y., 2016, Thermal and ash characterization of Indonesian bamboo and its potential for solid fuel and waste valorization, Int. J. Renewable Energy Dev., 5 (2), 95-100.

[10] ASTM C109M, 2007, Standard test method for compressive strength of hydraulic cement mortars (using 2-in. or [50-mm] cube specimens), ASTM International, West Conshohocken.

[11] Fletcher, R.A., MacKenzie, K.J.D., Nicholson, C.L., and Shimada, S., 2005, The composition range of aluminosilicate geopolymers, J. Eur. Ceram. Soc., 25 (9), 1471-1477.

[12] Yao, X., Zhang, Z., Zhu, H., and Chen, Y., 2009, Geopolymerization process of alkali-metakaolinite characterized by isothermal calorimetry, Thermochim. Acta, 493 (1-2), 49-54.

[13] Panagiotopoulou, Ch., Kontori, E., Perraki, Th., and Kakali, G., 2007, Dissolution of aluminosilicate minerals and by-products in alkaline media, $J$. Mater. Sci., 42 (9), 2967-2973.

[14] Sindhunata, Provis, J.L., Lukey, G.C., Xu, H., and van Deventer, J.S.J, 2008, Structural evolution of fly ash based geopolymers in alkaline environments, Ind. Eng. Chem. Res., 47 (9), 2991-2999.

[15] van Jaarsveld, J.G.S., and van Deventer, J.S.J., 1999, Effect of the alkali metal activator on the properties of fly ash-based geopolymers, Ind. Eng. Chem. Res., 38 (10), 3932-3941.

[16] Cioffi, R., Maffucci, L., and Santoro, L., 2003, Optimization of geopolymer synthesis by calcinations and polycondensation of a kaolinitic residue, Resour. Conserv. Recycl., 40 (1), 27-38.

[17] Sabitha, D., Dattatreya, J.K., Sakthivel, N., Bhuvaneshwari, M., and Sathik, S.A.J., 2012, Reactivity, workability and strength of potassium versus sodium-activated high volume fly ashbased geopolymers, Curr. Sci., 103 (11), 13201327.

[18] van Deventer, J.S.J., Provis, J.L., Duxson, P., and Lukey, G.C., 2007, Reaction mechanisms in the geopolymeric conversion of inorganic waste to useful products, J. Hazard. Mater., 139 (3), 506513. 
[19] Zhang, Z., Wang, H., Provis, J.L., Bullen, F., Reid, A., and Zhu, Y., 2012, Quantitative kinetic and structural analysis of geopolymers. Part 1. The activation of metakaolin with sodium hydroxide, Thermochim. Acta, 539, 23-33.

[20] Zhang, Z., Provis, J.L., Wang, H., Bullen, F., and Reid, A., 2013, Quantitative kinetic and structural analysis of geopolymers. Part 2. Thermodynamics of sodium silicate activation of metakaolin, Thermochim. Acta, 565, 163-171.

[21] Criado, M., Fernández-Jiménez, A., and Palomo, A., 2007, Alkali activation of fly ash: Effect of the
$\mathrm{SiO}_{2} / \mathrm{Na}_{2} \mathrm{O}$ ratio. Part I: FTIR study, Microporous Mesoporous Mater., 106 (1-3), 180-191.

[22] Febrero, L., Granada, E., Patiño, D., Eguía, P., and Regueiro, A., 2015, A comparative study of fouling and bottom ash from woody biomass combustion in a fixed-bed small-scale boiler and evaluation of the analytical techniques used, Sustainability, 7 (5), 5819-5837.

[23] Lee, W.K.W., and van Deventer, J.S.J., 2002, The effects of inorganic salt contamination on the strength and durability of geopolymers, Colloids Surf., A, 211 (2-3), 115-126. 